conductors, and of the small energy-gap which modern theory postulates as a characteristic of superconductors; values of the gap of $4 \cdot 3 k T_{c}$ and $3.6 k T_{c}$ are quoted for lead and indium, respectively. The region of negative resistance disappears when either metal of the sandwich is taken above its transition temperature; an applied magnetic field, by its control of $T_{c}$, can therefore modify the $I / V$ relationship, and at $1^{\circ} \mathrm{K}$. the current passed by one sandwich for an applied voltage of $0.2 \mathrm{mV}$. could be changed by a factor of $10^{5}$. These effects thus make possible active devices capable of amplifying, and of acting as bi-stable switches.

\section{The Torald Sollmann Award in Pharmacology}

Wyeth Laboratories of Philadelphia have established the Torald Sollmann Award in Pharmacology to commemorate the pioneer work in the United States of Dr. Torald Sollmann in the fields of pharmacological investigation and education. The Torald Sollmann Award consists of 2,500 dollars and a medal, and will be awarded for significant contemporary contribution to the advancement and extension of knowledge in the field of pharmacology. The Award is open to all scientists working in the field of pharmacology including, but not limited to, individuals from academic institutions, foundations, government and industrial and research organizations, regardless of age, sex or nationality. It will be given for originality and uniqueness of approach as well as development of the new concepts, theories and techniques which constitute a definite, mature and significant contribution to the extension and advancement of contemporary pharmacological knowledge. Not more than one Award will be made annually. Nominations for the Award must be submitted to the secretary of the Society (who is at present Prof. R. M. Featherstone, Department of Pharmacology, University of California, San Francisco 22) to be forwarded to the Chairman of the Torald Sollmann Award Committee not later than January 15 of each year to be eligible for consideration for an Award during the ensuing year. The first Award. will be made at the 1961 autumn meeting of the Society in Rochester.

\section{University News :}

Birmingham

THE following appointments have recently been made: G. R. Tzaak, to be research associate in nuclear physics in the Department of Physies; Dr. C. F. Wells, to be lecturer in the Department of Chemistry ; Dr. F. Bakhtar, to be lecturer in the Department of Mechanical Engineering; R. H. Hollier, to be Tube Investments Senior Research Fellow in the Department of Engineering Production; Mr. J. W. Fortey, to be lecturer in the Department of Civil Engineering; Mr. D. E. N. Davies, to be Associated Television Fellow in the Department of Electrical Engineering; Mr. B. Henderson, to be William Gibbins Research Fellow in the Department of Physical Metallurgy; Dr. A. T. Rees, to be Imperial Chemical Indus. tries Follow in Geophysics, in the Department of Geology ; Dr. C. E. Rowe, to be Caroline Harrold Research Fellow in the Department of Physiology.

Edinburgh

THE following have been appointed to lectureships : Dr. T. D. Patten (engineering) and Mr. D. C. Malcolm (forestry). Dr. J. L. Holmes and Dr. A. J. Charlson have been appointed Imperial Chemical Industries Research Fellows for three years.

\section{London}

Titues of professor in the University of London have been conferred on Dr. N. A. Barnicot (physical anthropology), in respect of his post at University College; Dr. L. F. Lamerton (biophysics as applied to medicine), in respect of his post at the Institute of Cancer Research : Royal Cancer Hospital. Titles of reader in the University of London have been conferred on Dr. R. H. Garstang (astronomy), in respect of his post at University College ; Dr. M. K. Wells (geology), in respect of his post at University College. Dr. M. D. Milne, lecturer at the Postgraduate Medical School of London, has been appointed to the University chair of medicine tenable at Westminster Medical School.

The following appointments to readerships have been announced: Dr. F. A. Goldsworthy (applied mathematics), tenable at Queen Mary College as from January 1, 1961; Mr. E. J. Ambrose (physical chemistryl, tenable at the Institute of Cancer Research : Royal Cancer Hospital; Dr. R. Creese (physiology), tenable at St. Mary's Hospital Medical School; Dr. L. Miles Jackman (organic chemistry), tenable at the Imperial College of Science and Technology; Mr. M. J. Way (applied entomology), tenable at the Imperial College of Science and Technology ; Dr. G. M. Timmis (chemistry), in respect of the post held by him at the Institute of Cancer Research: Royal Cancer Hospital; Dr. C. R. Webb (mechanical engineering), in respect of the post held by him at Queen Mary College; Dr. H. I. Winner (bacteriology), in respect of the post held by him at Charing Cross Hospital Medical School.

\section{Announcements}

Sir Cyrin Hinshelwood, Dr. Lee's professor of chemistry in the University of Oxford and past president of the Royal Society, has been awarded the Medal for 1961 of the Society of Chemical Industry. The Medal, a senior award of the Society, is presented every two years for conspicuous services to applied chemistry by research, discovery, invention or improvements.

Dr. William O. BaKer, vice-president of research at the Bell Telephone Laboratories, has been elected to the Board of Trustees of the Rockefeller Institute. Dr. Baker is also chairman of the National Science Information Council.

The five hundred and seventy-seventh meeting of the American Mathematical Society will be held at Hunter College, New York, N.Y., on February 25. Further information can be obtained from Everett Pitcher, American Mathematical Society, 190 Hope Street, Providence 6, Rhode Island.

A symposium on "Temperature-its Measurement and Control in Science and Industry" is being jointly sponsored by the American Institute of Physics, the Instrument Society of America and the National Bureau of Standards. The symposium will be held at Columbus, Ohio, during March 27-31. Further information can be obtained from V. W. Sikora, Instrument Society of America, 313 Sixth Avenue, Pittsburgh 22, Pennsylvania. 